\title{
Leuconostoc pseudoficulneum sp. nov., isolated from a ripe fig
}

\author{
Lélia Chambel, ${ }^{1}$ Ivo M. Chelo, ${ }^{1}$ Líbia Zé-Zé, ${ }^{1}$ Luis G. Pedro, ${ }^{2}$ \\ Mário A. Santos ${ }^{1}$ and Rogério Tenreiro ${ }^{1}$
}

Correspondence

Rogério Tenreiro rptenreiro@fc.ul.pt
Centro de Genética e Biologia Molecular and Instituto de Ciência Aplicada e Tecnologia, Edificio ICAT ${ }^{1}$ and Centro de Biotecnologia Vegetal and Departamento de Biologia Vegetal, Bloco C2², Universidade de Lisboa, Faculdade de Ciências, Campus da FCUL, Campo Grande, 1749-016 Lisboa, Portugal

Six strains of lactic acid bacteria (LAB) were isolated from a ripe fig. These strains constituted a highly homogeneous, but distinct, cluster that was separate from other LAB species in a polyphasic approach including dot-blot DNA-DNA hybridization, SDS-PAGE whole-cell protein profiling, carbohydrate fermentation ability, growth characteristics, enzymic profiling, pulsed-field gel electrophoresis macrorestriction analysis and RFLPs. Phylogenetic analysis based on 16S rRNA gene sequencing positioned a representative strain, $L C 51^{\top}$, in a distinct line of descent within the recently described clade comprising Leuconostoc ficulneum, Leuconostoc fructosum and Leuconostoc durionis; L. ficulneum was its closest neighbour (98\% sequence similarity). DNA-DNA hybridization values and chemotaxonomic and biochemical characteristics, including enzymic profiles detected with API ZYM microtubes, confirmed that this group of strains is distinct from $L$. ficulneum and represents a novel species within the genus Leuconostoc. Taking into account the common origin and phylogenetic proximity, the name Leuconostoc pseudoficulneum sp. nov. is proposed. Strain $\operatorname{LC} 51^{\top}\left(=\mathrm{DSM} 15468^{\top}=\right.$ CECT $\left.5759^{\top}\right)$ is the type strain; the DNA $\mathrm{G}+\mathrm{C}$ content of this strain is $44.5 \mathrm{~mol} \%$.
During a polyphasic taxonomic study of a collection of about 200 lactic acid bacteria (LAB), isolated from more than 50 different food products, a group of six strains $\left(\mathrm{LC} 51^{\mathrm{T}}\right.$, LC47, LC48, LC49, LC50 and LC52) were found to constitute a highly homogeneous cluster that was distinct from other LAB species. The polyphasic approach included dot-blot DNA-DNA hybridization, SDS-PAGE whole-cell protein profiling, carbohydrate fermentation ability, growth characteristics, enzymic profiling, pulsed-field gel electrophoresis (PFGE) macrorestriction analysis and RFLP analysis. The six strains were isolated from a ripe fig collected in the Alentejo region (Portugal) after sample enrichment in MRS broth ( $\mathrm{pH} 6 \cdot 5$; Merck) at $28^{\circ} \mathrm{C}$ for 6 days.

Cell morphology and motility were tested by phasecontrast microscopy of cells grown in MRS broth. Gram

\footnotetext{
Abbreviations: LAB, lactic acid bacteria; PFGE, pulsed-field gel electrophoresis.

The GenBank/EMBL/DDBJ accession number for the 16S rRNA gene sequence of strain $L C 51^{\top}$ is $A Y 169967$.

A table with fatty acid data and dendrograms depicting the relationships between the fig strains and type strains from several Leuconostoc and Weissella species derived from the independent analysis of phenotypic characteristics, whole-cell protein patterns and genomic data are available as supplementary material in IJSEM Online.
}

reaction, catalase test, production of gas from glucose and the presence of arginine dihydrolase, in MRS broth without ammonium citrate and with $0.3 \%(\mathrm{w} / \mathrm{v})$ arginine, were analysed as described by Gerhardt et al. (1994). The optical isomer of lactic acid was determined using a D/L-lactate dehydrogenase kit (Boehringer Mannheim). All strains were Gram-positive cocci, occurring singly or in pairs, catalase-negative, heterofermentative (produced gas and over $95 \%$ D-lactic acid from glucose) and arginine dihydrolase-negative. These characteristics were in accordance with their inclusion in the genera Leuconostoc (Garvie, 1986; Holt et al., 1994) or Weissella (Collins et al., 1993).

For identification at the species level and differentiation, isolated strains and reference strains from several species of the genera Leuconostoc and Weissella were cultivated in MRS broth at $30^{\circ} \mathrm{C}$ for $24 \mathrm{~h}$, except for protein extraction where MRS agar was used. DNA was extracted by the guanidine thiocyanate method (Pitcher et al., 1989) and used in all molecular assays, except for macrorestriction analysis (see below). Dot-blot DNA-DNA hybridization was performed in Hybond-N nylon membranes (Amersham), according to the standard procedures for high-stringency hybridization $\left(68^{\circ} \mathrm{C}\right)$ described by Sambrook et al. (1989), using 40 ng genomic DNA per dot and ${ }^{32} \mathrm{P}$-labelled DNA of each reference strain as probe (Multiprime DNA labelling system; 
Amersham). Autoradiographs were digitized and densitometric analysis was performed using the Kodak 1D software package version 3.5. Whole-cell protein extracts were obtained and analysed by SDS-PAGE according to Pot et al. (1994). Densitometric analysis, normalization and numerical analysis of the protein profiles were performed with the BioNumerics software package version 4.0 (Applied Maths). From the several diagnostic tables published for Leuconostoc and Weissella species, a total of 56 different tests was selected for phenotypic characterization, including fermentation of 41 carbohydrates of the API 50CHL system (bioMérieux), production of dextran from sucrose, yellow pigmentation, growth at different temperatures, $\mathrm{pH}$ values, $\mathrm{NaCl}$ concentrations and in the presence of $10 \%$ ethanol and hydrolysis of starch, gelatin and aesculin. Except for ethanol resistance, which was determined in a stoppered tube, TC24 culture plates (Nunc) were used for phenotypic tests with $1 \mathrm{ml}$ culture medium and following the general procedures described by Gerhardt et al. (1994). Fermentation tests were performed with $0.5 \%(\mathrm{w} / \mathrm{v})$ for each carbohydrate and a basal medium equivalent to FT80 medium (Cavin et al., 1989), without glucose, fructose and malic acid and with the $\mathrm{pH}$ adjusted to $6 \cdot 8$. All data from the phenotypic characterizations were recorded as positive/negative and numerical analysis was performed with BioNumerics software. Enzymic profiling was obtained with the API ZYM microtubes (bioMérieux), according to the manufacturer's instructions. After $12 \mathrm{~h}$ incubation at $37^{\circ} \mathrm{C}$, data were recorded both as positive/negative and on a scale of 0 to 5. Macrorestriction analysis with SmaI (CCCGGG) and AscI (GGCGCGCC) endonucleases was performed using agarose-immobilized unsheared genomic DNA and PFGE running conditions as described by Tenreiro et al. (1994). Genomic DNA was also digested with EcoRI, BamHI, HindIII and PstI frequent-cutting endonucleases and restriction fragments were separated by standard electrophoresis in $0.8 \%(\mathrm{w} / \mathrm{v})$ agarose gels. After visualization and digital image recording of restriction profiles, Southern blots were obtained (Sambrook et al., 1989) and ribotyping was performed using the digoxigenin PCR-labelled $16 \mathrm{~S}$ rRNA gene of Oenococcus oeni CECT $217^{\mathrm{T}}$ as a probe and a non-radioactive hybridization procedure, similar to that described by Alves et al. (2004). As for SDS-PAGE, genomic restriction profiles without hybridization were directly analysed with BioNumerics software. Macrorestriction and ribotyping data were collected as positive/negative from the densitometric analysis performed with Kodak 1D software and numerical analysis was performed with BioNumerics software.

To evaluate the relationships among the group of six fig strains and 19 type strains from species (or subspecies) of the genera Leuconostoc and Weissella, separate dendrograms were constructed derived from phenotypic characteristics, whole-cell protein patterns and genomic data (see Supplementary Figs S1-S3 available in IJSEM Online). Although different hierarchical relationships were observed among the type strains of Leuconostoc and Weissella species, the fig strains always formed a homogeneous and distinct cluster in each dendrogram, displaying levels of similarity with the most closely related species that were equivalent to or lower than those found between distinct type strains. As shown in Fig. 1, which results from numerical analysis integrating all available data, the strains isolated from the ripe fig constituted a coherent cluster displaying a low similarity level $(27 \%)$ with all type strains included in the study. Although some degree of variability among the six isolates was displayed in the dendrogram, a high similarity was obtained for protein profiles $(91 \%)$ and phenotypic tests (only isolate LC50 behaved differently by showing no growth with $6.5 \% \mathrm{NaCl}$ ), and no differences were observed

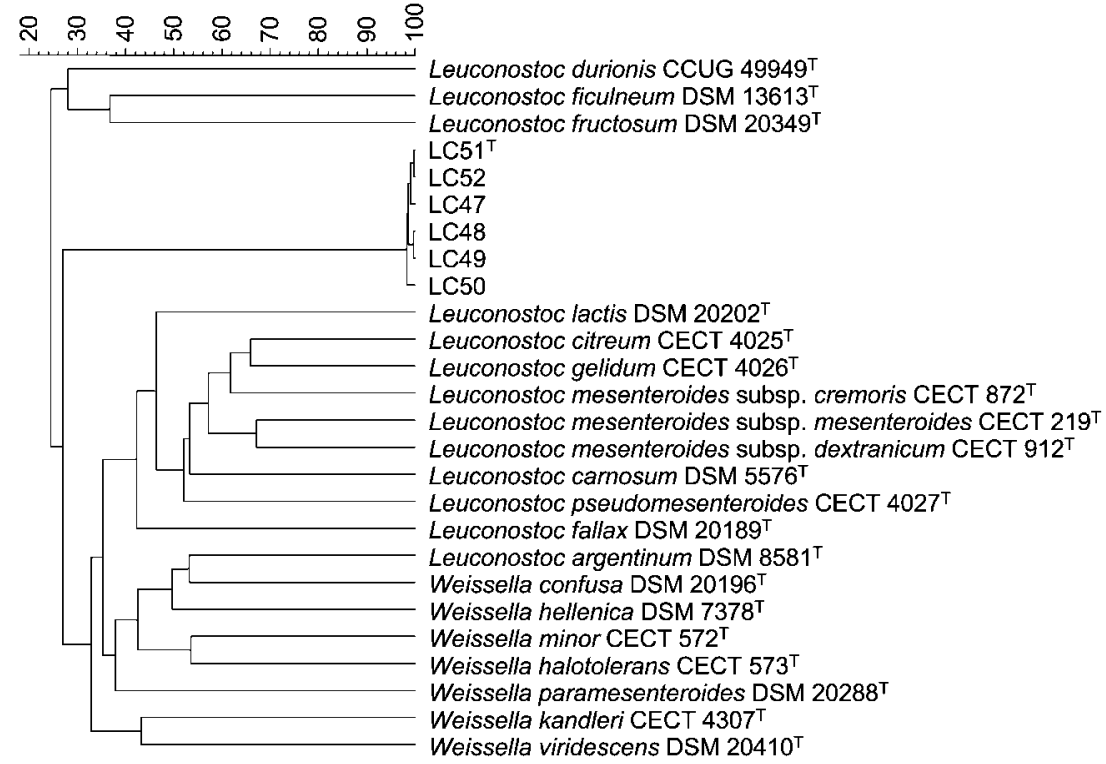

Fig. 1. Relationships between the group of six fig strains and type strains of several species of the genera Leuconostoc and Weissella. The dendrogram was constructed with UPGMA and a mean similarity matrix combining data from whole-cell protein profiles, phenotypic characteristics (carbohydrate fermentation, growth under different conditions, enzyme profiles), macrorestriction analysis and ribotyping. The scale corresponds to global percentage of similarity. The cophenetic correlation for the whole dendrogram is 0.95 . 
in macrorestriction profiles and ribotyping patterns. Since the strains were obtained from the same sample, these facts point to a close relationship among them; strain $\mathrm{LC} 51^{\mathrm{T}}$ was selected as the representative strain.

The 16S rRNA gene of strain LC51 ${ }^{\mathrm{T}}$ was amplified with the universal primers pA and $\mathrm{pH}$ (Edwards et al., 1989). PCR amplification was carried out as follows: denaturation at $94{ }^{\circ} \mathrm{C}$ for $4 \mathrm{~min} ; 35$ cycles of $1 \mathrm{~min}$ denaturation at $94^{\circ} \mathrm{C}$, $1 \mathrm{~min}$ annealing at $50^{\circ} \mathrm{C}$ and $2 \mathrm{~min}$ extension at $72^{\circ} \mathrm{C}$; and a final extension step at $72^{\circ} \mathrm{C}$ for $5 \mathrm{~min}$. The amplified fragment was purified with the Concert Rapid PCR Purification system (Gibco) and sequenced in an automated DNA capillary sequencer CEQ 2000-XL (Beckman Coulter) by a dye-labelled dideoxy termination method (Dye Terminator Cycle Sequencer start kit; Beckman Coulter). Sequencing reactions were performed using primers $\mathrm{pA}$ and $\mathrm{pH}$ and the internal primers 519R (5'-GWATTACCGCGGCKGCTG), 907R (5'-CCGTCAATTCMTTTRAGTTT), 926F (5'-AAACTYAAAKGAATTGACGG) and 1392r (5'-ACGGGCGGTGTGTRC) (Lane, 1991), as well as F1B (5'-GAACGCTGGCGGCGTGC) and F2 (5'-TATCCGGATTTATTGGGCGT). The $1494 \mathrm{bp}$ sequence of the LC51 ${ }^{\mathrm{T}}$ $16 \mathrm{~S}$ rRNA gene was compared with NCBI/GenBank entries using the BLAST algorithm (Altschul et al., 1997) and a high similarity $(98 \%)$ was found with Leuconostoc ficulneum. $16 \mathrm{~S}$ rRNA gene sequence similarities to other Leuconostoc species were in the range of 92-94\%, whereas only $87-88 \%$ similarity was found to sequences from Weissella species.

The position of strain LC51 ${ }^{\mathrm{T}}$ inside the Leuconostoc clade was determined by phylogenetic analysis. Previously published 16S rRNA gene sequences of type strains from species of Leuconostoc, Weissella and Oenococcus, as well as Lactobacillus delbrueckii (as outgroup), were obtained from GenBank and aligned with the sequence of strain LC $51^{\mathrm{T}}$ using CLUSTAL_X software. Evolutionary distance matrices were calculated (with both Jukes-Cantor and Kimura twoparameter models) and neighbour-joining phylogenetic trees were generated with 1000 replicate bootstrap analysis using the PHYLIP software package (Felsenstein, 1993). The phylogenetic tree obtained with the Kimura two-parameter model is depicted in Fig. 2. Highly congruent tree topologies were also observed with neighbour-joining (Jukes-Cantor model), maximum-likelihood and maximum-parsimony methods. Except for the peripheral clustering of Leuconostoc mesenteroides subsp. mesenteroides relative to the Leuconostoc lactis clade, obtained with the maximumlikelihood method, and the previously observed variable position of the O. oeni type strain relative to the Leuconostoc and Weissella clades (Tanasupawat et al., 2000; Lee et al., 2002), the four phylogenetic trees are in complete agreement, supporting the proposal of $\mathrm{LC} 1^{\mathrm{T}}$ as a representative of a novel species closely related to Leuconostoc ficulneum.

Based on 16S rRNA gene sequence analysis, the type strains of Leuconostoc ficulneum (DSM 13613 ${ }^{\mathrm{T}}$ ) and Leuconostoc fructosum (DSM 20349 ) were selected for dot-blot DNADNA hybridization experiments with the six fig strains. Strains DSM $13613^{\mathrm{T}}$ and DSM $20349^{\mathrm{T}}$ were grown in MRS broth supplemented with $2 \%$ fructose at $30^{\circ} \mathrm{C}$ for $24 \mathrm{~h}$, according to Antunes et al. (2002), and DNA was extracted as described above. Non-radioactive filter hybridization was performed with a positively charged nylon membrane (Roche) using $30 \mathrm{ng}$ DNA per dot and the Dig High-Prime DNA Labelling and Detection Starter kit II (Roche). Labelling of genomic DNA, stringent hybridization and washes, and luminescent detection were performed strictly according to the supplier's procedures. Results were observed by autoradiographic exposure and analysed with Kodak 1D software. As shown in Table 1, hybridization levels higher than $85 \%$ were observed among

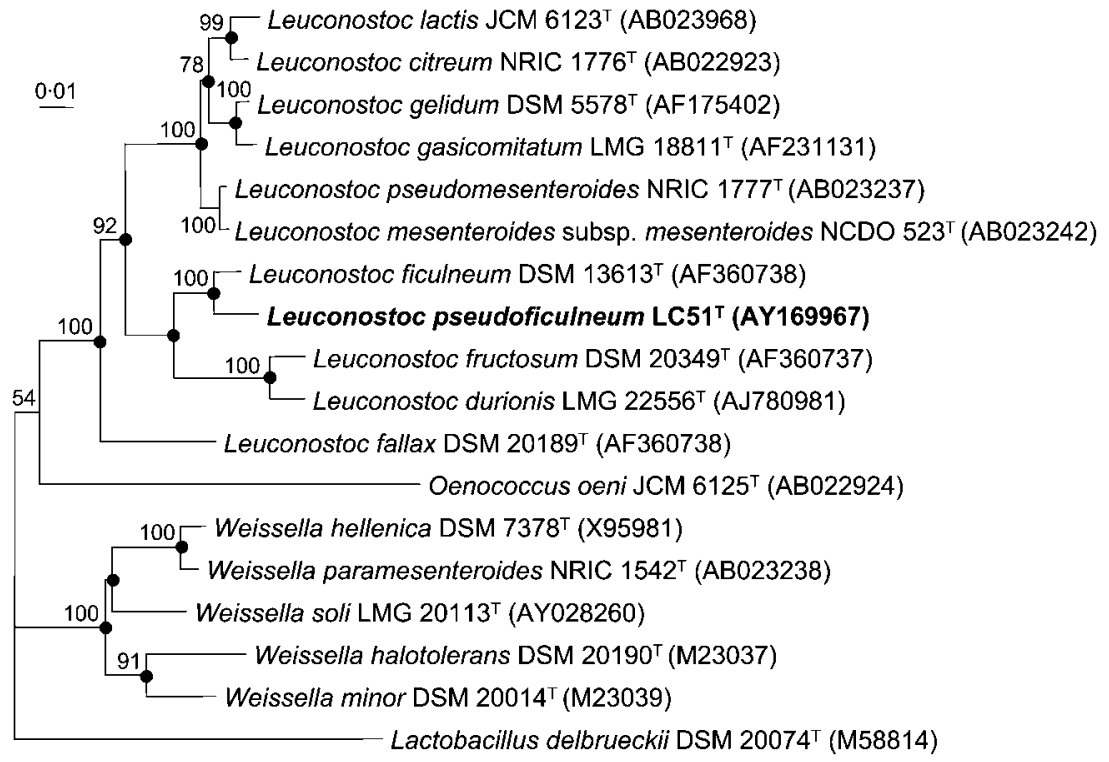

Fig. 2. Unrooted phylogenetic tree showing the relationships between Leuconostoc pseudoficulneum sp. nov. $\mathrm{LC} 51^{\top}$ and other species of the genera Leuconostoc, Weissella and Oenococcus. The tree was constructed using the neighbour-joining method (Kimura two-parameter model) and was based on a comparison of a consensus sequence of unambiguously aligned positions in the $16 \mathrm{~S}$ rRNA gene (1385 nt). Lactobacillus delbrueckii DSM $20074^{\top}$ was used as the outgroup. Numbers at nodes represent bootstrap values obtained from 1000 replicates and black dots indicate nodes (groups) that were also recovered using neighbour-joining (Jukes-Cantor model), maximum-likelihood and maximum-parsimony methods. Bar, $1 \%$ sequence divergence. 
Table 1. DNA-DNA hybridization levels among Leuconostoc pseudoficulneum sp. nov. and other LAB species

Values are means of duplicate determinations. ND, Not determined.

\begin{tabular}{|c|c|c|c|}
\hline \multirow[t]{2}{*}{ Source of unlabelled DNA } & \multicolumn{3}{|c|}{ Relatedness (\%) with labelled DNA from: } \\
\hline & $\operatorname{LC} 1^{\mathrm{T}}$ & DSM $13613^{T}$ & DSM $20349^{T}$ \\
\hline $\mathrm{LC} 51^{\mathrm{T}}$ & 100 & 16 & 7 \\
\hline LC47 & 85 & 18 & ND \\
\hline LC48 & 114 & 21 & 3 \\
\hline LC49 & 107 & 7 & 6 \\
\hline LC50 & 88 & 19 & 2 \\
\hline LC52 & 113 & 24 & 3 \\
\hline Leuconostoc ficulneum DSM $13613^{\mathrm{T}}$ & 56 & 100 & $\mathrm{ND}$ \\
\hline Leuconostoc fructosum DSM $20349^{\mathrm{T}}$ & 13 & 9 & 100 \\
\hline Weissella paramesenteroides DSM $20288^{\mathrm{T}}$ & 5 & 11 & 5 \\
\hline
\end{tabular}

the six fig strains, indicating that these strains belong to a single species. The lower relatedness values obtained with Leuconostoc ficulneum (7-24\%) confirm that the fig strains represent a novel species.

The DNA base composition of strain $\mathrm{LC} 51^{\mathrm{T}}$ was determined by HPLC as described by Kumura et al. (1991) using a Waters column Microbondapack $10 \mathrm{C}_{18}$, an isocratic flow of $0 \cdot 2 \mathrm{M} \mathrm{NH}_{4} \mathrm{PO}_{4}$ /acetonitrile and non-methylated phage lambda DNA as the calibration reference. The $\mathrm{G}+\mathrm{C}$ content of DNA of strain $\mathrm{LC}^{\mathrm{T}}{ }^{\mathrm{T}}$ was $44.5 \mathrm{~mol} \%$, which is almost identical to the value of $44 \mathrm{~mol} \%$ described for Leuconostoc durionis (Leisner et al., 2005) and close to the values of $42 \cdot 6$ and $43 \cdot 4 \mathrm{~mol} \%$ for Leuconostoc ficulneum and Leuconostoc fructosum, respectively (Antunes et al., 2002).

To analyse fatty acid composition, strains $\mathrm{LC} 51^{\mathrm{T}}$, DSM $13613^{\mathrm{T}}$ and DSM $20349^{\mathrm{T}}$ were grown in MRS agar plates at $30{ }^{\circ} \mathrm{C}$ for $48 \mathrm{~h}$ and fatty acid methyl esters were obtained by alkaline hydrolysis as described by Embley \& Wait (1994). The fatty acid methyl esters were separated by GC (FID Perkin Elmer 8700) and identified by GC-MS (Perkin Elmer Autosystem XL GC interfaced with a Perkin Elmer Turbo MS; software version 4.1). The identity of the components was determined by comparison of GC-MS data with corresponding data of NIST and of Wiley mass spectral libraries and of laboratory-synthesized components and commercially available standards from a homemade library. The double-bond position of unsaturated fatty acid methyl esters was determined by GC-MS of their dimethyl disulphide adducts. Data shown (\%) are mean values of two injections of each sample. The major fatty acids of strain LC5 $1^{\mathrm{T}}$ were 11,12 -octadecenoic acid $(18: 1 \Delta 11,18: 1 \omega 7 c)$ and hexadecanoic acid (16:0), corresponding to $40 \cdot 7$ and $31 \cdot 2 \%$, respectively. The unsaturated acids 9,10 -octadecenoic acid $(18: 1 \Delta 9,18: 1 \omega 9 c)$ and 9,10 -hexadecenoic acid $(16: 1 \Delta 9,16: 1 \omega 7 c)$ were also detected, at 13.6 and $9.8 \%$, respectively. As described by Antunes et al. (2002), these fatty acids were also observed, although in different relative amounts, in the type strains of Leuconostoc ficulneum and Leuconostoc fructosum (see Supplementary Table S1 available in IJSEM Online), thus reinforcing the discriminatory potential of fatty acid composition for this clade of Leuconostoc species. Compared to the results of Antunes et al. (2002), our data revealed smaller amounts of $18: 1 \Delta 11$ $(18: 1 \omega 7 c)$ and larger amounts of $18: 1 \Delta 9(18: 1 \omega 9 c)$ and 16:0 in the type strains of Leuconostoc ficulneum and Leuconostoc fructosum, corresponding to an overall increase in the saturated fatty acids. Similar differences were also found for the proportions of fatty acids in Leuconostoc pseudomesenteroides and Weissella paramesenteroides reported by Limonet et al. (2002) and Antunes et al. (2002). Nevertheless, an overall consistency was observed regarding the major identified fatty acids and quantitative differences may be explained by adaptation to different incubation conditions, since the growth temperature used in our study and by Limonet et al. (2002) was higher $\left(30^{\circ} \mathrm{C}\right)$ than that used in other studies.

The morphological and biochemical characteristics of strain $\mathrm{LC} 51^{\mathrm{T}}$ and the other five fig isolates are presented in the species description. As shown in Table 2, which summarizes the physiological differences between the novel strains and the most closely related species, both the Leuconostoc ficulneum/Leuconostoc fructosum and the Leuconostoc fallax clades are characterized by an overall inability to ferment carbohydrates when compared to the Leuconostoc mesenteroides clade. Although some differences were observed in the acid production profiles of the novel strains and Leuconostoc ficulneum, the weak or delayed response observed for them strongly impairs their use as discriminating characters. In fact, a similar situation was also observed for Leuconostoc mesenteroides subsp. mesenteroides and Leuconostoc pseudomesenteroides, as reported by Antunes et al. (2002) and Leisner et al. (2005). However, the use of API ZYM microtubes in our polyphasic study pointed to their usefulness for diagnostic purposes in this group of LAB using the growth conditions and procedures already described. From the comparison of 
Table 2. Physiological differences between Leuconostoc pseudoficulneum sp. nov. and related species

Strains: 1, Leuconostoc pseudoficulneum $\mathrm{LC}^{\mathrm{T}}{ }^{\mathrm{T}} ; 2$, Leuconostoc ficulneum DSM $13613^{\mathrm{T}} ; 3$, Leuconostoc fructosum DSM 20349 $;$ 4, Leuconostoc durionis LMG 22556 ${ }^{\mathrm{T}} ; 5$, Leuconostoc fallax DSM 20189 ${ }^{\mathrm{T}}$; 6 , Leuconostoc pseudomesenteroides DSM 20193 ${ }^{\mathrm{T}} ; 7$, Leuconostoc mesenteroides subsp. mesenteroides DSM $20343^{\mathrm{T}} ; 8$, Weissella paramesenteroides DSM $20288^{\mathrm{T}}$. Data were compiled from Antunes et al. (2002), Leisner et al. (2005) and this study. W, Weak; (d), delayed, ND, not determined.

\begin{tabular}{|c|c|c|c|c|c|c|c|c|}
\hline Characteristic & 1 & 2 & 3 & 4 & 5 & 6 & 7 & 8 \\
\hline \multicolumn{9}{|l|}{ Acid production from: } \\
\hline L-Arabinose & - & - & - & - & - & + & + & + \\
\hline Cellobiose & - & - & - & - & - & + & + & - \\
\hline Aesculin & - & - & - & - & + & + & + & - \\
\hline Galactose & - & - & - & - & - & + & + & (d) \\
\hline$\beta$-Gentiobiose & - & - & - & - & - & + & $\mathrm{W}$ & - \\
\hline Gluconate & - & (d) & - & + & - & - & - & $\mathrm{W}$ \\
\hline Lactose & - & - & - & - & - & - & (d) & $\mathrm{W}$ \\
\hline Mannitol & + & (d) & + & + & (d) & - & W & - \\
\hline Maltose & - & - & - & - & - & + & + & + \\
\hline D-Mannose & - & - & - & - & + & (d) & + & + \\
\hline Melibiose & - & - & - & - & - & + & + & ND \\
\hline D-Raffinose & - & - & - & - & - & + & + & - \\
\hline Ribose & - & - & - & + & - & + & + & (d) \\
\hline Starch & - & - & - & - & - & - & - & (d) \\
\hline Sucrose & - & $\mathrm{W}$ & - & + & + & + & + & + \\
\hline Trehalose & - & (d) & - & + & - & + & + & + \\
\hline D-Turanose & - & $\mathrm{w}$ & - & + & + & + & + & (d) \\
\hline D-Xylose & - & - & - & - & - & + & $\mathrm{ND}$ & - \\
\hline \multicolumn{9}{|c|}{ Enzyme activities (API ZYM microtubes) } \\
\hline Alkaline phosphatase & + & - & - & + & + & - & - & - \\
\hline$\alpha$-Chymotrypsin & + & + & + & + & - & - & - & - \\
\hline Leucine aminopeptidase & - & + & + & + & - & - & + & + \\
\hline Valine and cysteine aminopeptidases & - & - & - & + & - & - & - & - \\
\hline Lipase (C14) & - & - & - & + & - & - & - & - \\
\hline$\alpha$-Glucosidase & - & + & + & - & + & - & + & + \\
\hline
\end{tabular}

enzyme profiles, seven enzyme activities were shown to have diagnostic potential. As reported in Table 2, Leuconostoc ficulneum and Leuconostoc fructosum displayed an identical profile, but the novel strains, as well as Leuconostoc durionis, Leuconostoc fallax and Leuconostoc pseudomesenteroides, could be distinguished from Leuconostoc mesenteroides subsp. mesenteroides. Although application of the API ZYM system in the genus Leuconostoc has only been reported for two isolates of Leuconostoc gasicomitatum (Björkroth et al., 2000), its use in the characterization and discrimination of other groups of LAB has already been described (Arora et al., 1990; Collins et al., 1999; Lawson et al., 2000; Medina et al., 2001).

Phylogenetic analysis and DNA-DNA hybridization values, as well as chemotaxonomic and biochemical characteristics, including enzymic profiles detected with API ZYM microtubes, confirmed the distinctiveness revealed by the polyphasic study of this group of fig strains. The assignment of strains LC51 ${ }^{\mathrm{T}}$, LC47, LC48, LC49, LC50 and LC52 to a novel species within the genus Leuconostoc is thus in accordance with the phylophenetic concept of bacterial species (Rosselló-Mora \& Amann, 2001) and current recommendations for species definition (Stackebrandt et al., 2002). Taking into account the common origin and the phylogenetic proximity with Leuconostoc ficulneum, the name Leuconostoc pseudoficulneum sp. nov. is proposed.

\section{Description of Leuconostoc pseudoficulneum sp. nov.}

Leuconostoc pseudoficulneum [pseu.do.fi.cul'ne.um. Gr. adj. pseudes false; L. neut. adj. ficulneum of the fig-tree and also a bacterial specific epithet; N.L. neut. adj. pseudoficulneum not the true (Leuconostoc) ficulneum].

Cells are Gram-positive, ovoid and $0 \cdot 7-1 \cdot 1 \times 2 \cdot 2-3 \cdot 0 \mu \mathrm{m}$, occurring singly or in pairs. Cells are non-motile and nonspore-forming. Colonies are small, smooth, round, convex, opaque and greyish-white. Facultatively anaerobic. 
Heterofermentative; the lactate isomer is $\mathrm{D}(-)$. Catalase and cytochrome oxidase activities are not detected. Arginine dihydrolase is not produced. The optimum temperature for growth is approximately $30^{\circ} \mathrm{C}$; growth occurs at $37^{\circ} \mathrm{C}$, but not at $4^{\circ} \mathrm{C}$. The optimum $\mathrm{pH}$ for growth is between $6 \cdot 5$ and $7 \cdot 0$, but cells can grow at $\mathrm{pH} 4 \cdot 8$ and $8 \cdot 5$. Growth occurs in 3 and $5 \% \mathrm{NaCl}$, but not in $10 \% \mathrm{NaCl}$. Most strains, including the type strain, grow in $6.5 \% \mathrm{NaCl}$. No growth is observed in the presence of $10 \%$ ethanol. The predominant cellular fatty acids are 11,12-octadecenoic acid $(18: 1 \Delta 11,18: 1 \omega 7 c)$ and hexadecanoic acid $(16: 0)$. No yellow pigment is produced. Does not produce dextran from sucrose. Gelatin, starch and aesculin are not hydrolysed. Acid is produced from D-fructose, D-glucose and Dmannitol. Acid is not produced from D-adonitol, amygdalin, L-arabinose, D-arabitol, arbutin, cellobiose, dulcitol, aesculin, erythritol, D-fucose, D-galactose, $\beta$-gentiobiose, Dgluconate, glycerol, glycogen, inositol, inulin, lactose, Dlyxose, D-maltose, D-mannose, D-melezitose, D-melibiose, D-raffinose, L-rhamnose, D-ribose, salicin, D-sorbitol, Lsorbose, sucrose, D-trehalose, D-turanose, xylitol or Dxylose. Alkaline and acid phosphatases, phosphohydrolase and $\alpha$-chymotrypsin activities are detected in API ZYM microtubes.

The type strain is $\mathrm{LC} 1^{\mathrm{T}}\left(=\right.$ DSM $15468^{\mathrm{T}}=$ CECT $\left.5759^{\mathrm{T}}\right)$, isolated from a ripe fig collected in the Alentejo region, Portugal. The $\mathrm{G}+\mathrm{C}$ content of the type strain is $44.5 \mathrm{~mol} \%$ (as determined by HPLC).

\section{Acknowledgements}

I. M.C. and L.Z.-Z. are the recipients of research grants from FCT SFRH/BD/10675/2002 and SFRH/BPD/3653/2000, respectively. The authors thank Carla Rodrigues (Laboratory of Instrumental Analysis, Instituto de Ciência Aplicada e Tecnologia) for technical support in the DNA base composition analysis.

\section{References}

Altschul, S. F., Madden, T. L., Schaffer, A. A., Zhang, J., Zhang, Z., Miller, W. \& Lipman, D. J. (1997). Gapped BLAST and PSI-BLAST: a new generation of protein database search programs. Nucleic Acids Res 25, 3389-3402.

Alves, P. I., Martins, M. P., Semedo, T., Figueiredo Marques, J. J., Tenreiro, R. \& Barreto Crespo, M. T. (2004). Comparison of phenotypic and genotypic taxonomic methods for the identification of dairy enterococci. Antonie van Leeuwenhoek 85, 237-252.

Antunes, A., Rainey, F. A., Nobre, M. F., Schumann, P., Ferreira, A. M., Ramos, A., Santos, H. \& Da Costa, M. S. (2002). Leuconostoc ficulneum sp. nov., a novel lactic acid bacterium isolated from a ripe fig, and reclassification of Lactobacillus fructosus as Leuconostoc fructosum comb. nov. Int J Syst Evol Microbiol 52, 647-655.

Arora, G., Lee, B. H. \& Lamoureux, M. (1990). Characterization of enzyme profiles of Lactobacillus casei species by a rapid API ZYM system. J Dairy Sci 73, 264-273.

Björkroth, K. J., Geisen, R., Schillinger, U., Weiss, N., de Vos, P., Holzapfel, W. H., Korkeala, H. J. \& Vandamme, P. (2000). Characterization of Leuconostoc gasicomitatum sp. nov., associated with spoiled raw tomato-marinated broiler meat strips packaged under modified-atmosphere conditions. Appl Environ Microbiol 66, 3764-3772.

Cavin, J. F., Prevost, H., Lin, J., Schmitt, P. \& Divies, C. (1989). Medium for screening Leuconostoc oenos strains defective in malolactic fermentation. Appl Environ Microbiol 55, 751-753.

Collins, M. D., Samelis, J., Metaxopoulos, J. \& Wallbanks, S. (1993). Taxonomic studies on some leuconostoc-like organisms from fermented sausages: description of a new genus Weissella for the Leuconostoc paramesenteroides group of species. J Appl Bacteriol 75, 595-603.

Collins, M. D., Rodriguez Jovita, M., Lawson, P. A., Falsen, E. \& Foster, G. (1999). Characterization of a novel Gram-positive, catalase-negative coccus from horses: description of Eremococcus coleocola gen. nov., sp. nov. Int J Syst Bacteriol 49, 1381-1385.

Edwards, U., Rogall, T., Blocker, H., Emde, M. \& Bottger, E. C. (1989). Isolation and direct complete nucleotide determination of entire genes. Characterization of a gene coding for $16 \mathrm{~S}$ ribosomal RNA. Nucleic Acids Res 17, 7843-7853.

Embley, T. M. \& Wait, R. (1994). Structural lipids of eubacteria. In Chemical Methods in Prokaryotic Systematics, pp. 121-161. Edited by M. Goodfellow \& A. G. O'Donnell. Chichester: Wiley.

Felsenstein, J. (1993). PHYLIP (phylogenetic inference package), version 3.5c. Distributed by the author. Department of Genome Sciences, University of Washington, Seattle, USA.

Garvie, E. I. (1986). Genus Leuconostoc van Tieghem 1878. In Bergey's Manual of Systematic Bacteriology, vol. 2, pp. 1071-1075. Edited by P. H. A. Sneath, N. S. Mair, M. E. Sharpe \& J. G. Holt. Baltimore: Williams \& Wilkins.

Gerhardt, P., Murray, R. G. E., Wood, W. A. \& Krieg, N. R. (editors) (1994). Methods for General and Molecular Bacteriology. Washington, DC: American Society for Microbiology.

Holt, J. G., Krieg, N. R., Sneath, P. H. A., Staley, J. T. \& Williams, S. T. (editors) (1994). Bergey's Manual of Determinative Bacteriology, 9th edn. Baltimore: Williams \& Wilkins.

Kumura, K., Minamishima, Y., Yamamoto, S., Ohashi, N. \& Tamura, A. (1991). DNA base composition of Rickettsia tsutsugamushi determined by reversed-phase high-performance liquid chromatography. Int J Syst Bacteriol 41, 247-248.

Lane, D. J. (1991). 16S/23S rRNA sequencing. In Nucleic Acid Techniques in Bacterial Systematics, pp. 115-175. Edited by E. Stackebrandt \& M. Goodfellow. Chichester: Wiley.

Lawson, P. A., Foster, G., Falsen, E., Ohlen, M. \& Collins, M. D. (2000). Atopobacter phocae gen. nov., sp. nov., a novel bacterium isolated from common seals. Int J Syst Evol Microbiol 50, 1755-1760.

Lee, J.-S., Lee, K. C., Ahn, J.-S., Mheen, T.-I., Pyun, Y.-R. \& Park, Y.-H. (2002). Weissella koreensis sp. nov., isolated from kimchi. Int J Syst Evol Microbiol 52, 1257-1261.

Leisner, J. J., Vancanneyt, M., van der Meulen, R. \& 8 other authors (2005). Leuconostoc durionis sp. nov., a heterofermenter with no detectable gas production from glucose. Int J Syst Evol Microbiol 55, $1267-1270$

Limonet, M., Revolt-Junelles, A.-M. \& Millière, J.-B. (2002). Variations in the membrane fatty acid composition of resistant or susceptible Leuconostoc or Weissella strains in the presence or absence of mesenterocin $52 \mathrm{~A}$ and mesenterocin $52 \mathrm{~B}$ produced by Leuconostoc mesenteroides subsp. mesenteroides FR52. Appl Environ Microbiol 68, 2910-2916.

Medina, R., Katz, M., Gonzalez, S. \& Oliver, G. (2001). Characterization of the lactic acid bacteria in ewe's milk and cheese from northwest Argentina. J Food Prot 64, 559-563.

Pitcher, D. G., Saunders, N. A. \& Owen, R. J. (1989). Rapid extraction of bacterial genomic DNA with guanidium thiocyanate. Lett Appl Microbiol 8, 151-156. 
Pot, B., Vandamme, P. \& Kersters, K. (1994). Analysis of electrophoretic whole-organism protein fingerprints. In Modern Microbial Methods (Chemical Methods in Prokaryotic Systematics Series), pp. 493521. Edited by M. Goodfellow \& A. G. O’Donnell. Chichester: Wiley.

Rosselló-Mora, R. \& Amann, R. (2001). The species concept for prokaryotes. FEMS Microbiol Rev 25, 39-67.

Sambrook, J., Fritsch, E. F. \& Maniatis, T. (1989). Molecular Cloning: a Laboratory Manual, 2nd edn. Cold Spring Harbor, NY: Cold Spring Harbor Laboratory.

Stackebrandt, E., Frederiksen, W., Garrity, G. M. \& 10 other authors (2002). Report of the ad hoc committee for the re-evaluation of the species definition in bacteriology. Int J Syst Evol Microbiol 52, 1043-1047.

Tanasupawat, S., Shida, O., Okada, S. \& Komagata, K. (2000). Lactobacillus acidipiscis sp. nov. and Weissella thailandensis sp. nov., isolated from fermented fish in Thailand. Int J Syst Evol Microbiol 50, 1479-1485.

Tenreiro, R., Santos, M. A., Paveia, H. \& Vieira, G. (1994). Interstrain relationships among wine leuconostocs and their divergence from other Leuconostoc species, as revealed by low frequency restriction fragment analysis of genomic DNA. J Appl Bacteriol 77, 271-280. 